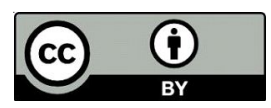

UDC 81’25:35.077.535.6

LBC 81.18
Submitted: 14.12 .2020

Accepted: 30.03 .2021

\title{
TRANSLATION GENIUS AND SOCIAL NETWORKS
}

\author{
Innara A. Guseynova \\ Moscow State Linguistic University, Moscow, Russia
}

\author{
Alexey I. Gorozhanov \\ Moscow State Linguistic University, Moscow, Russia \\ Elena S. Kudinova \\ Moscow State Linguistic University, Moscow, Russia
}

\begin{abstract}
The paper attempts to consider changes in the translator's activity caused by the turn towards digital transformation in the institutional sphere. The analysis is based on material from German social networks, their content being the subject matter for the modern translator who is a specialist in cross-cultural and crosslingual communication. The study describes the algorithm for implementing social management at the macrostructural and compositional levels. The emphasis is also placed on the institutional spheres that are most susceptible to digital transformation, which include nutrition and healthy lifestyle, education and many others. Total digital transformation of these institutional spheres is primarily evidenced by an increase in neologisms recorded in electronic databases, and dictionaries with an indication of their contextual use and their further popularization, first of all, in mass media texts. The results of the analysis lead the authors to conclude that training a new generation of interpreters and translators should include mastering the skill of working with big data, different corpora of texts, neologisms marked by or containing the industry component, as well as the need to develop glossary-type dictionaries for branches of knowledge. Considering the controversial content of social networks, the authors of the paper come to the conclusion that it is necessary to develop the code of ethics for the social networks translator.
\end{abstract}

Key words: institutional communication, cross-cultural communication, cross-lingual communication, translation theory, translation practice, audiovisual content, digital transformation, social management tool.

Citation. Guseynova I.A., Gorozhanov A.I., Kudinova E.S. Translation Genius and Social Networks. Vestnik Volgogradskogo gosudarstvennogo universiteta. Seriya 2. Yazykoznanie [Science Journal of Volgograd State University. Linguistics], 2021, vol. 20, no. 3, pp. 55-64. DOI: https://doi.org/10.15688/jvolsu2.2021.3.5

УДК 81 '25:35.077.535.6

Дата поступления статьи: 14.12 .2020

ББК 81.18 Дата принятия статьи: 30.03.2021

\section{ГЕНИЙ ПЕРЕВОДЧИКА И СОЦИАЛЬНЫЕ СЕТИ}

\author{
Иннара Алиевна Гусейнова \\ Московский государственный лингвистический университет, г. Москва, Россия
}

Алексей Иванович Горожанов

Московский государственный лингвистический университет, г. Москва, Россия

Елена Сергеевна Кудинова

Московский государственный лингвистический университет, г. Москва, Россия 
Аннотация. В статье реализована попытка рассмотреть изменения в деятельности переводчиков, вызванные поворотом к цифровой трансформации институциональной сферы. А.И. Горожановым проведен анализ речевого материала немецких социальных сетей, содержание которых является предметом изучения современного переводчика, специализирующегося на межкультурном и межъязыковом общении. Е.С. Кудиновой описан алгоритм реализации социального управления на макроструктурном и композиционном уровнях. Акцент сделан на институциональных сферах, наиболее подверженных цифровой трансформации (питание и здоровый образ жизни, образование и др.). Установлено, что о тотальной цифровой трансформации этих институциональных сфер свидетельствует увеличение количества неологизмов, зафиксированных в электронных базах данных, словарях с указанием их контекстного использования, и их активная воспроизводимость в текстах средств массовой информации. И.А. Гусейновой обобщены результаты исследования и сделан вывод о том, что подготовка устных и письменных переводчиков нового поколения должна включать работу с большими данными, опираться на разные корпусы текстов, способствовать освоению неологизмов, имеющих отраслевую составляющую; выявлена потребность переводчиков в словарях типа глоссария по отраслям знаний. Учитывая неоднозначное содержание социальных сетей, авторы статьи аргументируют необходимость разработки этического кодекса переводчика социальных сетей.

Ключевые слова: институциональная коммуникация, межкультурная коммуникация, межъязыковая коммуникация, теория перевода, практика перевода, аудиовизуальный контент, цифровая трансформация, инструмент социального управления.

Цитирование. Гусейнова И. А., Горожанов А. И., Кудинова Е. С. Гений переводчика и социальные сети // Вестник Волгоградского государственного университета. Серия 2, Языкознание. - 2021. - Т. 20, № 3. - С. 55-64. - (На англ. яз.). - DOI: https://doi.org/10.15688/jvolsu2.2021.3.5

\section{Introduction}

Digital transformation has a significant impact on various occupations, which, in terms of translation activities, necessitates the exploration of the following range of questions. First, it is important to determine the impact of the global turn towards digital transformation on experts in cross-cultural and cross-lingual communication. Secondly, we need to clarify the material the modern translator will have to work with under conditions of digital economy. Thirdly, it is necessary to define efficient training of a new generation of translators, ensuring their comfortable work during digital transformation, which primarily implies systematizing labor functions of experts in cross-cultural and crosslingual communication.

Digital transformation calls for developing interdisciplinary research bases that integrate achievements of STEM and humanities, providing, among other things, a correlation of linguistic and mathematical knowledge [Amelkin, Ivanova, 2011]. A close look at various databases shows their global and ubiquitous Anglo-Americanization, which is naturally due to economic factors: the use of English in computer-mediated communication makes it possible for comprehensive cost saving on the communicative-discourse continuum, from teaching foreign languages in general and higher education, to creating an institutional environment in which professional interaction is carried out through lingua franca, whose status has been claimed by English for many decades, despite other widely spoken languages, such as Russian, Chinese, Arabic, Spanish, French, German and others. Many foreign scholars also note that $80 \%$ of scientific information is published in international databases in English, while the remaining 20\% account for the other languages. This applies to different areas of knowledge, including healthcare, etc., compare: 'First, the outcomes are presented of our analysis of the Faculty of Medicine at University of Münster (Germany). Figure 1 shows per year-block the total output of the faculty (including papers in all languages), and the output in English-language journal publications only. The share of the latter is about $80 \%$ of the former, which means that $20 \%$ of the output consists of non-English language journal publications' [Leeuwen et al., 2001, p. 338]. The lingua franca status of British and American English is largely observed in social networks, which are dynamic in nature and can absorb resources of different languages to solve communication problems. For this reason, many researchers deem it necessary to single out Internet communication as a separate area of research [Ashnin, 2015; Evtushenko, Pervukhina, 2020; Ibatova, Gromova, 2021; Karasik, 2012]. 
We consider the scientific point of view of a number of scientists to be very efficient, but we believe it is important to conduct an analysis in a broader vein, which will allow us to see future development of virtual space, to identify possible risks and dangers for sociocultural interaction in the institutional sphere. We see high potential to carry out an analysis based on the material of widely spoken languages, which include both Russian and German. With regard to the Russian language of social networks, works of a plethora of scientists should be noted [Klimanova, Dembovskaya, 2013; Kolesnikov, 2018; Kostomarov, 2019; Ovchinnikova, 2013; Saakyan, 2016]. As for German, the study of changes is carried out mainly in Germany and Austria, which is evidenced by modern publications on the problem [Bedijs, Heyder, 2020; Dittler, Hoyer, 2014], while in Russian German studies, such work is carried out mainly within the framework of youth science - in bachelor's and master's theses. Undoubtedly, achievements of Russian and foreign German studies are presented in Russian scientific series publications [Yazyk i moda, 2017], but their fragmentary presence in the Anglo-American scientific community makes German studies more vulnerable, however, at the same time helps to preserve its best traditions.

In our work, we will focus on interdisciplinary scientific research carried out within the framework of various projects implemented by experts in German language and culture and based on material of German social networks, which is relevant for training experts in cross-cultural and cross-lingual communication.

\section{Results and discussion}

\section{Peculiarities of German social networks}

It bears reminding that in modern linguistic studies devoted to analysis of empirical facts taken from social networks, attempts are constantly being made to break down the virtual space into genres [Mityagina, Sidorova, 2016; Russkaya germanistika..., 2008]. This systematization is complicated by the hybrid nature of Internet genres, as well as their dynamic development across different platforms. Despite the fact that the main networks are considered to be Facebook, Twitter, WhatsApp, their language varies greatly. This is primarily due to the fact that all social networks are oriented on a specific target audience, in which certain sociolinguistic parameters prevail - gender, age, social status, gender, etc. The pragmatic aspect has a significant impact on sociocommunicative practices, as well as on the macrostructure, or social media content. However, it should be mentioned that anonymization and pseudonymization make it possible for people to be present in various social networks and actively interact with social groups, thereby leveling out all sociolinguistic parameters, including gender, which we interpret, following the majority of scholars, as the sociocultural gender [Gorodnikova, 1999; 2002; Kostarnova, 2020]. It is for this reason that many foreign researchers reflect on the 'postfeminist era', which they regard as the historical development of feminism, or, what is more important to us, as part of modern transformations, cf. English: 'A contrasting perspective regards postfeminism as an historical shift within feminism, or as part of its on-going transformation' [Litosseliti, Gill, Favaro, 2019 , p. 4]. Gender transformations will pose new challenges for practicing translators in terms of specificity of particular languages. Eliminating the gender factor in modern texts often leads to the loss of gender identity and, at the same time, to the popularization of gender constructs in other linguocultures, where gender is explicitly represented by the lexical and grammatical means of the language itself - e.g. the gender category in the language system and structures, etc.

The global turn towards digital transformation forced members of various ethnic societies to dramatically reconsider their attitude to objects and world phenomena, which was reflected in discursive and communicative practices in various professional spheres. At the linguistic level, this manifested itself in the widespread distribution in the German-speaking community both in everyday and institutional environment of the concept of 'Lohas', which in terms of word formation in German, is an abbreviation and goes back to 'Lifestyle of Health and Sustainability' [Klosa-Kückelhaus, Schnedermann, 2019, p. 22]. Obviously, such a concept, rooted in the recipient's collective consciousness, will lead to changes in social networks content, which, in turn, will result in an increase in such nouns as 'Veganer / Vegetarier' - 
a vegetarian, a person who consumes plants; 'Frutarier' is a person whose eating habits include fruits, etc. The emergence of a corpus of texts that address a healthy lifestyle will require communication channels for their dissemination mass media, radio, television, etc. As a result, the translator will have to know the relevant diet programmes, foods recommended for consumption, as well as patterns of generating advertisements and video content. In addition, it should be recalled that these concepts, in accordance with the specificity of German, will give rise to derivatives, for example, 'Teilzeitvegetarier'. In the light of the above, in relation to the translator's profession, the role of glossaries, both mono- and multilingual, will also increase, which will include information about a particular phenomenon that marks a healthy lifestyle. To illustrate our point, let us consider the following example: the concept of 'Superfood', which arose no more than 10 years ago: 'Superfood - Nahrungsmittel, dem besonders viele Vitamine und andere wertvolle Inhaltsstoffe und damit eine besondere gesundheitsfördernde Wirkung zugeschrieben wird' [Klosa-Kückelhaus, Schnedermann, 2019, p. 24]. Such an explanation makes it possible to translate the concept of 'Superfood', and further popularization of this good without adequate representation in advertising or medical discourse poses a challenge. As digital transformation evolves, the lifestyle itself is changing, and in the future, so is the social behavior of individuals, as well as certain communities united by common interests and preferences. For this reason, the appearance of lexical units reflecting the new reality across social networks should be expected. In witness whereof, we will give specific examples from German social networks: 'Couchpotato / Couchkartoffel; Homing; Cocooning' [Klosa-Kückelhaus, 2020, pp. 1-2]. It is beyond argument that it is possible to reveal the content of the abovementioned lexemes from the point of view of translation practice only through working with data corpuses and analyzing the contextual use of the lexical units, which do not mean potatoes at all ('Couchpotato / Couchkartoffel'), but refer to people who lead a sedentary lifestyle and prefer to stay in for no apparent reason or need, cf. German: 'Mit diesen Wörtern werden Menschen bezeichnet, die ihre
Freizeit vorzugweise sitzend verbringen' [Klosa-Kückelhaus, 2020, p. 1]. Homing should be interpreted as remaining indoors, where the home is seen as a center for organizing one's leisure time, cf. German: 'Zuhause als Mittelpunkt der Freizeitgestaltung' [KlosaKückelhaus, 2020, p. 2]. Cocooning is nothing more than a desire to isolate oneself from the outside world, to 'wrap in a cocoon'. From this perspective, we should talk about the sociocommunicative elements of the translator's professional discourse and socio-communicative strategies [Naumova, 2013], which help to take into account the creative initiative in the translator's practice, which is objectified through the use of various linguistic means, which at the same time bring out the translator's individuality.

Social networks, due to the variety of content broadcast through various communication channels, require the modern translator to make well-grounded, not so much translation decisions, as ideological, philosophical and pragmatic decisions, which will make it possible to create the final translation taking into account the specificity of the social services commissioning by enterprises and companies that offer digital services.

\section{Social networks as a tool for managing social reality}

The fact of managing real ethnosociety through social networks is objectified at the linguistic level. Let's turn to specific examples in German: 'mailen, anmailen, simsen, bloggen, posten, skypen, whatsappen' [KlosaKückelhaus, Schnedermann, 2019, p. 46], cf. Russian: 'писать по электронной почте, направлять смс-сообщение, размещать пост / постировать, вести блог, выходить на связь через скайп, общаться по вотсап$n y$ '. At first glance, we are talking about lexemes that mark Internet communication. However, a more profound analysis of lexical units, using sociolinguistic research methods, elements of content analysis, theory of discourse and communication allows us to come to the following conclusion: not only do units 'mailen, bloggen, twittern' express communication technologies that serve mediated communication, but they also define the sociolinguistic parameters of group 
communities. The technical channel for disseminating and transmitting information, helps determine the social status, sociocultural level, job functions, the level of information competence of the participant in virtual communication. In this light, the activities of an interpreter and translator become more complicated, because to adequately translate the content of social networks, they unwittingly have to consider the sociolinguistic parameters 'wired' in information communication channels - blog, twitter, whatsapp, etc.

Also complicated becomes an interpreter' and a translator's work which is affected by the 'shift' towards imagery and visualization. As a result, this shift pushes the verbal mode to the background. The decrease in verbal descriptions enhances the emotional component, which results in the use of emoticons that indicate the attitude and assessment of the subject of communication by participants in virtual interaction [Provine, Spencer, Mandell, 2007]. This is especially noticeable in the summary of comments in German in such genres as talk shows, interviews and other entertainment formats. Simplification of verbal content takes communication to an emotional level, which makes it possible to determine the parameters of the target audience quickly and with a high degree of accuracy, which is important for marketing in all economic sectors. In written cross-cultural and cross-lingual communication, this gives rise to emoticons with a steadily growing repertoire. There is no need to interpret emoticons, but it does not rule out the linguistic and cultural or linguocultural commentary in translation, which is essential to consider while training future translators [Mityagina, Gureeva, 2017].

Social group management is also implemented at the macrostructural level. The analysis of some popular German social networks demonstrates the subject matter of issues under discussion. These are transformations taking place in schooling and higher education, cf. German: 'Veränderungen im Schul- und Hochschulwesen'; search of a life partner, cf. German: 'Partnersuche'; new team-building computer games, cf. German: 'Neue Teamspiele' [Klosa-Kückelhaus, Schnedermann, 2019, p. 24]. All thematic groups are characterized by certain key words, which function as a social signal for the mainstream recipient who is interested in taking part in communication on a particular topic. These keywords also perform a password function. Their regular use forms the 'profile' of a member of a given social group, and the data helps to establish the communicant's interests his taste preferences, emotional states, mood, etc. In other words, the data helps to define the sociocultural profile of a member of this social group, which is inclusive of common features. For the modern interpreter / translator, this means mastering the key words that mark communication on an issue. If the terminology base can be isolated through text corpora and methods of corpus-based and corpus-driven linguistics, working with social networks requires knowledge of passwords professional terms, heritage language lexemes, dialectisms and other linguistic means. Otherwise, the translator runs the risk of making communicative-pragmatic blunders.

Social networks are also managed at the compositional level. After all, the format of each social network has its given parameters that must be implemented by all participants in group communication, and at the same time it is supported by the structural elements of the pre-set communication genre. Failure to comply with certain compositional requirements leads to the fact that the participant of the social network stands in stark contrast to the rest of the group members, thus eliciting different reactions from other participants. This feedback is often critical, which causes discomfort and the group member either obeys the general rules or is forced to leave the communication group. The abovementioned circumstances stimulate genre forms of Internet communication. At the moment, we can single out social groups that prefer communication in such genres as blog, chat, news, etc. According to observations of German researchers, social networks are going through the following trend: each participant entering into indirect communication relies not on the topic, but on comments posted earlier. In other words, we are talking about forming space in which other people's opinion is ignored, which is due to the attempt of new participants to 'fit' into the established format. Translation of social network content lead to the translator involuntarily becoming a 'hostage' of the formats, which leads to his emotional workload, which in some cases reduces the qualitative and quantitative indicators of his activity. Realizing that 
there is another message behind the statement, the translator adheres to the pre-set composition.

Social networks are also managed at the institutional level. Examples are the regular surveys conducted in Germany collecting information about the attitude of Germans to the state of the German language, as well as the attitude of members of the German-speaking community to other foreign languages and cultures. According to German scholars, the interest in the status of German, both in Germany and abroad, is on the rise, which necessitates regular sociolinguistic surveys. Among various questions addressing the dialect proficiency of German native speakers, the areas of their use in day-to-day communication etc., special mention goes to two key themes: 1) the attitude of Germans to the German language; 2) the attitude of Germans to other (foreign) languages, which are used for various reasons in Germany. With regard to the first key question, survey participants emphasize the need to comply with the spelling rules, and to take into account the gender factor, cf. German: 'Geschlechtsgerechte Sprache' [Adler, Ribeiro Silveira, 2020, p. 22]. The survey results regarding the second key question specify that French, English, Italian and Spanish are 'attractive' for the Germans, cf. German: 'Als sympathische Sprachen werden insbesondere Französisch, Englisch, Italienisch und Spanisch genannt' [Adler, Ribeiro Silveira, 2020, p. 19]. The 'unattractive' languages' in the German-speaking community include Polish, Russian, Turkish and Arabic, cf. German: 'eher nicht sympathisch bewertet werden dagegen Polnisch, Russisch, Türkisch und Arabisch' [Adler, Ribeiro Silveira, 2020, p. 19]. It is beyond argument that the division of languages into 'attractive' and 'unattractive' is provisional, but it stimulates the study of cultural, historical, sociopolitical and other reasons for such an attitude towards specific languages. In the light of the institutional management of social networks, the abovementioned facts are of prime importance, as they draw attention to language policy in the context of migration, to globalization results and to imbuing virtual space with relevant content. To this effect, translator training requires considering theoretical modules that contribute to encyclopedic world knowledge, which is essential for the success of cross-cultural and cross-lingual communication.
In summary it can be said that for the modern translator should enhance her professional theoretical and practical training. Working with content involves managing big data, corpora of texts and making use of a certain thematic group of words, including units of special vocabulary, terminology, professional terms, emotive units, etc., i.e. the comprehensive set of linguistic means that is crucial to convey the meanings and information in the native or foreign language. In the professional community, a translator will be defined as an expert in a particular subject area and branch of knowledge.

\section{Functions of social media translator or traps lurking for the modern translator's / interpreter's genius}

In modern sociolinguistic publications, the term 'vitality' of languages is increasingly introduced into scientific context. In this sense, it seems appropriate to mention two types of vitality: linguistic and sociolinguistic. Russian authors define the linguistic vitality of a language as 'the ability for constant linguistic innovation, which manifests itself in reactions to external influences arising from contacts with other languages (both majoritarian and minoritarian languages)' [Bogdanov, Marusenko M.A., Marusenko N.M., 2020, p. 316]. Sociolinguistic vitality does not so much define the ability 'to adapt and develop the lexical-semantic and grammatical systems, but as the will (or strength) of the linguistic community to transmit its language or language variant to the next generations' [Bogdanov, Marusenko M.A., Marusenko N.M., 2020, p. 316]. Digital transformations, while affecting languages, at the same time 'check' the degree of their vitality, resistance to external influences. To illustrate the phenomenon of language resistance used in German social networks, let us examine the results of our observations, which directly relate to the translator's activity and present certain challenges for her.

Neologisms. German social networks are characterized by the use of verbs containing the components 'fremd' and 'gegen', cf. German: 'Fremd-Verben' und 'Gegen-Verben' [MüllerSpitzer, Ribeiro-Silveira, 2019, p. 16]. Among 
them, there are lexical units that pose a certain difficulty for the translator, for example, 'fremdschämen' and 'fremdevaluieren'. In reference editions, these verbs are not listed, which leads to the translator looking for possible translation options either in corpuses or in electronic glossary-type dictionaries explaining their meaning, since even native speakers are not always ready to immediately provide an everyday definition of these lexemes. Nevertheless, the verb 'fremdschämen', which is quite popular in German social networks, is interpreted as 'feeling ashamed for any words and actions committed by third parties', and the verb 'fremdevaluieren' is a term found in the field of pedagogy, and it can be translated as 'carrying out an independent diagnosis'.

Content stylization according to tastes and preferences of social groups. The analysis of German social networks reveals certain trends in the use of grammatical means. So, in the course of the analysis of the 'weil / denn' connectors on Facebook, it was found that age characteristics play a significant role in their use - 'weil' is used at a more mature age, while the use of 'denn' is typical for schoolchildren, for example, in essays, cf. German: 'Die Studie legt nahe, dass in Facebook-Texten eine Präferenz für den Konnektor weil vorliegt, wohingegen in Texten von Schüler / -innen häufiger denn verwendet wird' [Bröcher, Herzberg, 2019, p. 5]. In addition, Facebook discourse is defined by independent sentences that begin with the conjunction word 'weil', although according to the rules of German grammar, the word ' $d a$ ' is used at the beginning of a sentence, and a subordinate clause without the main clause is not used independently. This knowledge is crucial for the translator working with social networks, since it is these little things that testify to his professionalism.

Acceptance or non-acceptance of conventions and rules dictated by the employer at the institutional level. Not only does stepwise management of social networks require a high level of translation competence, but also compliance with the translator's code of ethics and rules for the translator's work with content. In this sense, the legal and ethical aspects of a translator's work is subject to further analysis and will require reviewing many rules and regulations that maintain interaction and dialogue between the machine (computer) and a human being, as well as taking into account new formats of work caused by the global turn towards digital transformation.

Recognizing post-feminist culture phenomena. Due to the fact that translators work with languages of different structure, and complete coincidence is a rather rare phenomenon in cognate languages, there arises the question of conveying the gender factor, which is blurred in virtual space or is impossible to recognize, since the participants in group communication use pseudonyms or hide their gender identity. Anonymity makes it possible to form pseudoidentity, which undoubtedly complicates translation, given grammatical differences in languages. The technologies of working with gender constructs in the linguistic aspect in the time of digital transformation are still poorly understood, which does not yet help us to give any recommendations that could be taken into account in interpreter and translator training.

\section{Conclusion}

This paper touches upon only part of the problems that directly relate to interpreter and translator training, their professional competence, and work in the time of digital transformation. However, today it is necessary to consider incorporating work with neologisms in the theory and practice of translation, compiling glossarytype dictionaries, working with various databases, which make it possible to reveal the meaning of new words that mark changes in everyday life and institutional spheres. The digital transformation of a translator's activity poses a challenge to his genius, but at the same time requires institutional support, for example, the development of a social media translator's code of ethics. We believe that training to analyze the facts of postfeminist culture is both forwardlooking and crucial.

\section{REFERENCES}

Adler A., Ribeiro Silveira M., 2020. Spracheinstellungen in Deutschland - Was die Menschen in Deutschland über Sprache denken. IDS Sprachreport, vol. 36, iss. 4, pp. 16-24. DOI: 10.14618/sr-4-2020-adl. 
Amelkin S.A., Ivanova O.S., 2011. Predelnye vozmozhnosti peredachi informatsii $v$ makrosistemakhc [Limiting Possibilities of Transmission of Information in an Economic Macrosystem]. Modelirovanie $i$ analiz informatsionnykh sistem [Modeling and Analysis of Information Systems], vol. 18, no. 3, pp. $75-81$.

Ashnin E.S., 2015. Metaforicheskaya reprezentatsiya mentalnykh operatsiy subyekta $\mathrm{v}$ yazyke nemetskoy molodezhi [Metaphorical Representation of the Subject's Mental Operations in the Language of German Youth]. Vestnik Volgogradskogo gosudarstvennogo universiteta. Seriya 2. Yazykoznaniye [Science Journal of Volgograd State University. Linguistics], no. 1 (25), pp. 125-133. DOI: http:// dx.doi.org/10.15688/jvolsu2.2015.1.14.

Bedijs K., Heyder K.H., 2020. Sprache und Personen im Web 2.0. Hildesheimer Beiträge zur Medienforschung, Band 1, Münster, Lit Varlag. $176 \mathrm{p}$.

Bogdanov S.I., Marusenko M.A., Marusenko N.M., 2020. Yazykovye perepisi i monitoringi kak instrument natsionalnoi $i$ yazykovoi politiki [Language Censuses and Monitoring as a Tool of National and Language Policy], Saint Petersburg, Rossiyskiy gosudarstvennyy pedagogicheskiy universitet im. A. I. Gertsena. $343 \mathrm{p}$.

Bröcher L., Herzberg L., 2019. Deutsch in sozialen Medien. Interaktiv - multimodal - vielfältig: Bericht von der 55. Jahrestagung des LeibnitzInstituts für deutsche Sprache, Mannheim, 1214. März 2019. IDS Sprachreport, vol. 35, iss. 2, pp. 2-8.

Dittler U., Hoyer M., 2014. Social Network-Die Revolution der Kommunikation. Kundenkommunikation, Facebook-Freundschaften, digitale Demokratie und virtuelle Shitstorms unter medienpsychologischer und mediensoziologischer Perspektive. München, kopaed. 341 p.

Evtushenko O.A., Pervukhina S.V., 2020. Elektronnyi modus sovremennogo administrativnogo diskursa [Electronic Mode of the Modern Administrative Discourse]. Vestnik volgogradskogo gosudarstvennogo universiteta. Seriya 2. Yazykoznaniye [Science Journal of Volgograd State University. Linguistics], vol. 19, no. 5, pp. 99-109. DOI: https://doi.org/10.15688/jvolsu2.2020.5.9.

Gorodnikova M.D., 1999. Gendernyi faktor i raspredelenie sotsialnykh rolei v sovremennom obshchestve: Na materiale brachnykh obyavlenii [Gender and the Distribution of Social Roles in Modern Society: Based on the Material of
Marriage Announcements]. Gendernyi faktor $v$ yazyke i kommunikatsii: sb. nauch. tr. [Gender Factor in Language and Communication: Collection of Scientific Papers], Moscow, Rema Publ., pp. 36-44.

Gorodnikova M.D., 2002. Gender v kommunikativnoi interaktsii [Gender in Communicative Interaction]. Gender: yazyk, kultura, kommunikatsiya: doklady Vtoroi mezhdunarodnoi konferentsii [Gender: Language, Culture, Communication: Reports of the $2^{\text {nd }}$ International Conference], Moscow, MGLU, pp. 70-76.

Ibatova A., Gromova A., 2021. Intercultural Features of Non-Verbal Means of Communication Used in Internet Communication. Applied Linguistics Research Journal, vol. 5, iss. 1, pp. 101-108. DOI: 10.14744/alrj.2021.98215.

Karasik V.I., 2012. Kompyuternaya igra «StarCraft»: lingvokulturnye kharakteristiki [Computer Game "StarCraft": Linguocultural Characteristics]. Internet-kommunikatsiya kak novaya rechevaya formatsiya [Internet Communication as a New Speech Formation], Moscow, Flinta Publ. 328 p.

Klimanova L., Dembovskaya S., 2013. L2 Identity, Discourse, and Social Networking in Russian. Language Learning \& Technology, vol. 17, iss. 1, pp. 69-88.

Klosa-Kückelhaus A., 2019. Bloggst du noch oder twitterst du schon? (Aus der Rubrik: Neuer Wortschatz. IDS Sprachreport, vol. 35, iss. 4, pp. 46-49.

Klosa-Kückelhaus A., 2020. Von Nichtstun und Erholung (An Weihnachten und $\mathrm{zu}$ anderen Zeiten) (aus der Rubrik Neuer Wortschatz). IDS Sprachreport, vol. 36, iss. 4, pp. 1-5. DOI: 10.14618/sr-4-2020-klosa.

Klosa-Kückelhaus A., Schnedermann T., 2019. Sind Sie auch schon ein Lohas? (aus der Rubrik Neuer Wortschatz). IDS Sprachreport, vol. 35, iss. 3. pp. 22-25.

Kolesnikov A.E., 2018. Yazyk seti internet i amerikanizatsiya russkogo yazyka [The Language of the Internet and the Americanization of the Russian Language]. Molodoy uchenyy, no. 20 (206), pp. 446-448.

Kostarnova O.S., 2020. Gendernye aspekty sovremennoy bytovoy italyanskoi skazki [Gender Aspects of the Modern Domestic Italian Tale]. Nauka bez granits: sinergiya teorii, metodov i praktik: materialy Mezhdunarodnoi nauchnoi konferentsi [Science Without Borders: Synergy of Theory, Methods and Practice: Proceedings of the International Scientific Conference], Moscow, MGLU, pp. 515-518. 
Amelkin S.A., Ivanova O.S., 2011. Predelnye vozmozhnosti peredachi informatsii $v$ makrosistemakhc [Limiting Possibilities of Transmission of Information in an Economic Macrosystem]. Modelirovanie $i$ analiz informatsionnykh sistem [Modeling and Analysis of Information Systems], vol. 18, no. 3, pp. $75-81$.

Ashnin E.S., 2015. Metaforicheskaya reprezentatsiya mentalnykh operatsiy subyekta $\mathrm{v}$ yazyke nemetskoy molodezhi [Metaphorical Representation of the Subject's Mental Operations in the Language of German Youth]. Vestnik Volgogradskogo gosudarstvennogo universiteta. Seriya 2. Yazykoznanie [Science Journal of Volgograd State University. Linguistics], no. 1 (25), pp. 125-133. DOI: http:// dx.doi.org/10.15688/jvolsu2.2015.1.14.

Bedijs K., Heyder K.H., 2020. Sprache und Personen im Web 2.0. Hildesheimer Beiträge zur Medienforschung, Band 1. Münster, Lit Varlag. $176 \mathrm{p}$.

Bogdanov S.I., Marusenko M.A., Marusenko N.M., 2020. Yazykovye perepisi i monitoringi kak instrument natsionalnoi $i$ yazykovoi politiki [Language Censuses and Monitoring as a Tool of National and Language Policy]. Saint Petersburg, Rossiyskiy gosudarstvennyy pedagogicheskiy universitet im. A. I. Gertsena. $343 \mathrm{p}$.

Bröcher L., Herzberg L., 2019. Deutsch in sozialen Medien. Interaktiv - multimodal - vielfältig: Bericht von der 55. Jahrestagung des LeibnitzInstituts für deutsche Sprache, Mannheim, 1214. März 2019. IDS Sprachreport, vol. 35, iss. 2, pp. 2-8.

Dittler U., Hoyer M., 2014. Social Network-Die Revolution der Kommunikation. Kundenkommunikation, Facebook-Freundschaften, digitale Demokratie und virtuelle Shitstorms unter medienpsychologischer und mediensoziologischer Perspektive. München, kopaed. 341 p.

Evtushenko O.A., Pervukhina S.V., 2020. Elektronnyi modus sovremennogo administrativnogo diskursa [Electronic Mode of the Modern Administrative Discourse]. Vestnik volgogradskogo gosudarstvennogo universiteta. Seriya 2. Yazykoznanie [Science Journal of Volgograd State University. Linguistics], vol. 19, no. 5, pp. 99-109. DOI: https://doi.org/10.15688/jvolsu2.2020.5.9.

Gorodnikova M.D., 1999. Gendernyi faktor i raspredelenie sotsialnykh rolei v sovremennom obshchestve: Na materiale brachnykh obyavlenii [Gender and the Distribution of Social Roles in Modern Society: Based on the Material of
Marriage Announcements]. Gendernyi faktor $v$ yazyke i kommunikatsii: sb. nauch. tr. [Gender Factor in Language and Communication: Collection of Scientific Papers]. Moscow, Rema Publ., pp. 36-44.

Gorodnikova M.D., 2002. Gender v kommunikativnoi interaktsii [Gender in Communicative Interaction]. Gender: yazyk, kultura, kommunikatsiya: doklady Vtoroi mezhdunarodnoi konferentsii [Gender: Language, Culture, Communication: Reports of the $2^{\text {nd }}$ International Conference]. Moscow, MGLU, pp. 70-76.

Ibatova A., Gromova A., 2021. Intercultural Features of Non-Verbal Means of Communication Used in Internet Communication. Applied Linguistics Research Journal, vol. 5, iss. 1, pp. 101-108. DOI: 10.14744/alrj.2021.98215.

Karasik V.I., 2012. Kompyuternaya igra «StarCraft»: lingvokulturnye kharakteristiki [Computer Game "StarCraft": Linguocultural Characteristics]. Internet-kommunikatsiya kak novaya rechevaya formatsiya [Internet Communication as a New Speech Formation]. Moscow, Flinta Publ. 328 p.

Klimanova L., Dembovskaya S., 2013. L2 Identity, Discourse, and Social Networking in Russian. Language Learning \& Technology, vol. 17, iss. 1, pp. 69-88.

Klosa-Kückelhaus A., 2019. Bloggst du noch oder twitterst du schon? (Aus der Rubrik: Neuer Wortschatz. IDS Sprachreport, vol. 35, iss. 4, pp. 46-49.

Klosa-Kückelhaus A., 2020. Von Nichtstun und Erholung (An Weihnachten und $\mathrm{zu}$ anderen Zeiten) (aus der Rubrik Neuer Wortschatz). IDS Sprachreport, vol. 36, iss. 4, pp. 1-5. DOI: 10.14618/sr-4-2020-klosa.

Klosa-Kückelhaus A., Schnedermann T., 2019. Sind Sie auch schon ein Lohas? (aus der Rubrik Neuer Wortschatz). IDS Sprachreport, vol. 35, iss. 3. pp. 22-25.

Kolesnikov A.E., 2018. Yazyk seti internet i amerikanizatsiya russkogo yazyka [The Language of the Internet and the Americanization of the Russian Language]. Molodoy uchenyy, no. 20 (206), pp. 446-448.

Kostarnova O.S., 2020. Gendernye aspekty sovremennoy bytovoy italyanskoi skazki [Gender Aspects of the Modern Domestic Italian Tale]. Nauka bez granits: sinergiya teorii, metodov i praktik: materialy Mezhdunarodnoi nauchnoi konferentsi [Science Without Borders: Synergy of Theory, Methods and Practice: Proceedings of the International Scientific Conference]. Moscow, MGLU, pp. 515-518. 
Kostomarov V.G., 2019. O displeinykh tekstakh [About Display Texts]. Russkiy yazyk za rubezhom [Russian Language Abroad], no. 1 (272), pp. 61-64.

Leeuwen Van Th.N., Moed H.F., Tijssen R.J.W., Visser M.S., Raan Van A.F.J., 2001. LanguageBiases in the Coverage of the Science Citation Index and its Consequences of International Comparisions of National Research Performance. Scientometrics. Leiden, Leiden University, vol. 51, pp. 335-346. DOI: 10.1023/A:1010549719484.

Litosseliti L., Gill R., Favaro L.G., 2019. Postfeminism as a Critical Tool for Gender and Language Study. Gender and Language, vol. 13, no. 1, pp. 1-22. DOI: $10.1558 /$ genl.34599.

Mityagina V.A., Gureeva A.A., 2017. Kommunikativnaya kompetentsiya perevodchika $\mathrm{V}$ epokhu global'nogo informatsionnogo prostranstva [The Communicative Competence of a Translator in the Era of the Global Information Space]. Yazyk $i$ lichnost $v$ garmonichnom dialoge kultur: materialy Mezhdunarodnoi nauchnoi konferentsii [Language and Personality in a Harmonious Dialogue of Cultures: Proceedings of the International Scientific Conference]. Stavropol, Paragraph Publ., pp. 325-329.

Mityagina V.A., Sidorova I.G., 2016. Zhanry personalnogo Internet-diskursa: kommunikativnye eksplikatsii lichnosti [The Genres of the Personal Internet Discourse: Communicative Explications of a Person]. Zhanry rechi [Speech Genres], no. 2(14), pp. 106-115. DOI: 10.18500/2311-0740-2016-2-14106-115.

Müller-Spitzer C., Ribeiro-Silveira M., 2019. Fremdschämen muss sich jeder Mal, aber haben Sie schon einmal von Fremdpflegen oder Fremdküssen gehört? Eine Studie zur Akzeptabilität und zum Neologismenstatus von
Fremd-Verben. IDS Sprachreport, vol. 35, iss. 3, pp. 16-21.

Naumova A.P., 2013. Institutsional'nost' professional'nogo diskursa perevodchikov [Institutionality of Professional Translators' Discourse]. Vestnik Volgogradskogo gosudarstvennogo universiteta. Seriya 2. Yazykoznanie [Science Journal of Volgograd State University. Linguistics], no. 2 (18), pp. 104-109.

Ovchinnikova I.G., 2013. Kommunikatsiya i identifikatsiya v sotsialnykh setyakh: faktory, tipazhi, natsionalno-kulturnaya spetsifika (na materiale sotsialnoi seti twitter) [Communication and Identification in Social Networks: Factors, Types, Ethnic and Cultural Specifics (Based on the Material of the Social Network Twitter)]. Vestnik Permskogo universiteta. Politologiya [Bulletin of Perm University. Political Science], no. 2 (22), pp. 143-156.

Provine R.R., Spencer R.J., Mandell D.L., 2007. Emotional Expression Online - Emoticons Punctuate Website Text Messages. Journal of Language and Social Psychology, vol. 26, iss. 3, pp. 299-307. DOI: 10.1177/0261927X06303481.

Saakyan L.N., 2016. Novye media: yazyk smi i sotsial'nykh setei [New Media: the Language of the Mass Media and Social Networks]. Russkiy yazyk za rubezhom [Russian Language Abroad], no. 4 (257), pp. 93-99.

Russkaya germanistika. T. V. Tipologiya tekstov novogo vremeni: ezhegodnik Rossiyskogo soyuza germanistov [Russian Germanistics. Vol. 5. Typology of Texts of Modern Times. Yearbook of the Russian Union of Germanists], 2008. Moscow, Yazyki slavyanskoykultury. 403 p.

Yazyk i moda: sb. st. [Language and Fashion. Collection of Articles], 2017. Moscow, s. n. 166 p. (Series: Theory and History of Linguistics). 